\title{
William James and the development of \\ phenomenological psychology in Europe
}

\author{
MAX HERZOG
}

In sum, then, my effort has been to offer in a 'natural science' of the mind a modus vivendi in which the most various schools may meet harmoniously on the common basis of fact. (William James)

\section{'PHENOMENOLOGICAL PSYCHOLOGY'}

If we are to write of 'phenomenological psychology' we first require a clarification of the relationship between phenomenology and psychology. That is not easy: for these two elements are highly variable along synchronic and diachronic dimensions (cf. Graumann, 1991; Herzog, 1992). Even before Edmund Husserl made the step from descriptive psychology in his Logical Investigations (1900-1) to the transcendental phenomenology in his Ideas (1913) there were differing conceptions of the nature of psychology and of phenomenology. The meaning of 'phenomenological psychology' was even less clear.

Viewed historically, three relational determinants within the complicated entanglement of psychology and phenomenology can be discerned. First of all, for Husserl phenomenology is merely a propaedeutic, a transitional stage on the way to a pure (philosophical) phenomenology. Secondly, within the phenomenological movement there are not a few psychologists who see things exactly in reverse: phenomenology as a means used in the methodical orientation of 
science. Thirdly, before Husserl there did exist a phenomenologically oriented psychology, in the same way that a phenomenological psychology flourished after Husserl that, strictly speaking, had little to do with his programme.

Hence the position of the American William James with respect to the European phenomenological movement varies depending on which of these three relational determinants is selected. Thus:

1 James's psychology is treated as the outcome of an intensive debate with the European forerunners of phenomenology; or

2 James's Principles of Psychology constitutes the foundation for Husserl's phenomenological philosophy; or

3 James's work is employed as a critique of Husserl's one-sided, constitutionally parenthetical phenomenology of the act, and then made into the basis for an objectivizing material phenomenology.

One has therefore to resist the assumption that the question of James's influence on the phenomenological movement should, naturally, take Husserl as its point of departure. Even if Husserl did play a leading role in its breakthrough, phenomenological psychology is also embedded in the work of Franz Brentano, Henri Bergson, Carl Stumpf and Ernst Mach. James responded to the work of these writers and formed on this basis a phenomenological unity. The place of honour as a founder of phenomenological psychology therefore belongs to James. In the decades following Husserl phenomenological psychology was developed in the writings of Frederik J. J. Buytendijk, Maurice Merleau-Ponty, Erwin Straus, Helmuth Plessner and many others. But William James preceded them. And that calls for some prefatory remarks on this particular reception process. ${ }^{1}$

\section{THE RECIPROCAL HISTORY OF THE RECEPTION OF JAMES AND HUSSERL}

James's importance for phenomenology was first discovered in America around mid-century, prompted by an appreciation of Husserl's own growing reputation. European phenomenology and the American reception of James as an exponent of pragmatism remained in a condition of mutual ignorance up to the Second World War. It was then that emigré European phenomenologists such as Alfred Schütz and Aron Gurwitsch drew American attention to James as a phenomenologist, while at the same time in the European context indicating the importance of James as well as Husserl for the phenomenological movement.

An additional motivation for this rediscovery of James as an American phenomenologist was the crisis into which phenomenological psychology entered after Husserl's 'transcendental turn', a shift which likewise affected European phenomenology in general. This crisis arose out of the step taken by 
Husserl from his Logical Investigations (1900-1) to his Ideas of 1913; a move which will be examined below. By contrast, American interest in postHusserlian European phenomenology led to reflection on the roots of this movement in the work of James, and to his reassessment as a phenomenologist in North America.

The reception of the relation between James and Husserl was 'unidirectional' (Edie, 1970:487). Not only was James recognized in his lifetime by prominent European writers such as Stumpf, Bergson, Mach and Husserl; it was also European phenomenologists who emphasized James's importance to postHusserlian philosophy and psychology - foremost here were Moritz Geiger, Alfred Schütz and Aron Gurwitsch. There was no counterpart to this from the other side of the Atlantic. James never knew the extent to which he had influenced Husserl, and until recently even commentators on Husserl took scarce note of such influence.

Let us consider those places in Husserl's writings which refer explicitly to James: on Husserl's own authority we can date his first reading of James to 1891-2, prompted by Stumpf (Biemel, 1956:295, n. 4). At that time Husserl was a Privatdozent lecturing in psychology at Halle during the winter semester of 1891-2. He writes:

Then came the lectures on psychology in 1891/92, which gave me occasion to examine the writings of descriptive psychology, longingly anticipated. James' psychology, of which I could only read a few pieces and very little at that, provided a few flashes. I saw how an acute and original man let himself be bound by no tradition; and how he sought to grasp and describe that which he contemplated. This influence was certainly not without its effect upon me, although I was only able to read and understand a few pages. Yes, to describe and to be exact, that was extremely necessary. But I did not read and make notes upon larger sections of his writings until after the appearance of my treatise of $1894 .^{2}$ (Husserl cited in Biemel, 1956: 294 f.)

The following assessment of James, linked to his critique of psychologism, appears in Husserl's Logical Investigations, the work which first made the phenomenological method famous:

James does not modernise ... Humean philosophy. And how little James' genial observations in the domain of a descriptive psychology of imaginary experiences require a psychologism can be seen from this text. For the encouragement which I took from this excellent researcher in descriptive analysis has only furthered my detachment from the psychologistic point of view. (Husserl, 1980, II/1:208, n. 1)

Husserl prefaced his lectures on 'The Principal Aspects of Phenomenology and the Theory of Knowledge', delivered during the winter semester of 1905-6, 
with explicit references to James: for example, the statement that there is a great deal of common ground shared between Husserl's own views and those of 'James, whom I have studied and whose work has greatly inspired me' (Husserl, 1969: xvi).

Husserl's personal copy of James's Principles of Psychology contains marginal comments, notes and translations in his own hand. Moreover, his library contained most of James's publications (Linschoten, 1961:3 f., n. 11). One trace of James's influence can be emphasized here, for it provides exemplary evidence of the critical influence 3 of James's psychology on the shaping of the axiom of intentionality in Husserl's phenomenology. James had sent Husserl an offprint of his 1895 article 'The Knowing of Things Together', later republished in part in 'The Tigers of India'. Husserl's copy of this can be found today in the Husserl-Archiv in Löwen. The following passage is underlined (Linschoten, 1961: $72 \mathrm{f}$.):

Most men would answer that what we mean by knowing the tigers is having them, however absent in body, become in some way present to our thought; or that our knowledge of them is known as presence of our thought to them. A great mystery is usually made of this peculiar presence in absence; and the scholastic philosophy, which is only common sense grown pedantic, would explain it as a peculiar kind of existence, called intentional inexistence, of the tigers in our mind. (James, 1948: 361-2)

Other passages in Husserl's work which refer to James present nothing new in one important respect: in comparison with the demonstrable influence of James upon Husserl, there is very little in the way of an appreciation of the American on the part of Husserl himself, not to mention subsequent commentary upon Husserl. That could well be linked to an incident that caused Husserl some offence.

Walter B. Pitkin has claimed that James turned the publishing house of Mifflin against Husserl and thus obstructed the publication in America of Pitkin's translation of the Logical Investigations. It is true that James distanced himself from contemporary Continental European logic. But it is clear that he had not seen either a copy of the second volume of the Logical Investigations, or Pitkin's translation of the Prolegomena. Moreover, there were no books by Husserl in James's personal library.

[The] story that it was James who had advised Houghton Mifflin against publishing Walter B. Pitkin's translation of the Logical Investigations, which grieved Husserl so much, is almost certainly a legend based on Pitkin's ambiguous report to Husserl at the time and his later fanciful autobiography. James' disinterest [sic], during his last years of intensified hostility to logic, in a new German logician, is, however, plausible enough. (Spiegelberg, 1984: 100 f.)

Nonetheless, Husserl took such offence at this incident that he never again expressed regard for James as a phenomenologist. 
But Husserl's terminological borrowings from James are quite apparent - for example, when Husserl talks of a 'stream of consciousness', or 'fiat'. For the substantive parallels between Husserl's phenomenological analyses of conscious elements and James's own psychological investigations in his Principles of Psychology were quite obvious to Husserl's own students. Alfred Schütz made a systematic inventory of these parallels (1966). Intentionality, stream of consciousness and horizon are a few of the central themes which connect James and Husserl and which point to a rupture in the contemporary discussion of epistemology: the prevailing tradition of Idealism, dating back to Kant, was breached, and this took place through what we know today as the 'New Realism'.

I will seek to elaborate, from the position of this New Realism, some substantive shared elements which can be shown to represent a common phenomenological foundation for the work of James and Husserl; a foundation which was already available for Husserl in the Principles of Psychology.

\section{NEW REALISM}

Seen from the standpoint of intellectual history, the New Realism was the expression of a phenomenological turning-point in the last quarter of the 19th century. It has a dual significance: as a critique of dogmatism, and as the establishment of a new concept of reality. Fullerton dubbed the latter 'New Realism' (1908: $32 \mathrm{f}$.), as a stance traceable to the work of the European Henri Bergson and the American William James (Kallen, 1914: 31).

The key phenomenological argument of New Realism was directed against a confusion of thought and experience (James, 1909:225 ff.). James contended that experience was a function of reality, in contrast to the thesis advanced by positivistic realism that experience consisted of an isomorphic relationship between the knower and the known (Miller, 1976:57). James dubbed this contention 'radical empiricism':

To be radical, an empiricism must neither admit into its constructions any element that is not directly experienced, nor exclude from them any element that is directly experienced. (James, 1912:42)

This presupposition is likewise embodied in James's psychology. James deliberately gave to the article of 1884 in which he first developed his path-breaking notion of 'stream of consciousness' the title 'On Some Omissions of Introspective Psychology' (1983:142 ff.). James was one of the first to translate into a scientific context the 'principle of all principles' as Husserl later called it. ${ }^{4}$ In James's investigation of the 'sense of sameness', in the distinction between 'knowing about' and 'being acquainted with', in the emphasis upon the immutability of 'conceptions' and of the active character of the subjective act of 
relating to something - here James presented the first results of impartial psychological description, anticipating Husserl's phenomenological concept of intentionality. Let us now deal in somewhat greater detail with the most important of these arguments.

\section{THE PHENOMENOLOGICAL CONCEPT OF INTENTIONALITY}

The concept of intentionality employed both by James and by Husserl can be traced back to Franz Brentano (1838-1917). In his Principles of Psychology James makes liberal reference to Brentano's key work, Psychology from the Empirical Standpoint; and his central chapter on the 'Stream of Thought' is heavily influenced by Brentano. James himself stated that what Brentano had written on the unity of consciousness is 'as good as anything with which I am acquainted' (James, 1902, I: 240).

There is also a chronological coincidence at work here that is certainly more than mere accident: during the winter semester of 1890-1 Brentano for the first time lectured in Vienna University on 'psychognosis'. By this title (a distant analogy to 'geognosy' and 'geology') Brentano sought to differentiate descriptive from genetic psychology. This latter form he characterized as natural scientific in character, inductive and primarily physiological. In 1890 Principles of Psychology appeared, which James opened with the succinct assertion that 'Psychology is the Science of Mental Life, both of its phenomena and of their conditions' (1902, I: 1$)$.

James's theses concerning the nature of intentionality took from Brentano the psychical primacy of reality founded, as a cognitive presence, upon consciousness - this point of departure is echoed in the passage cited above concerning our knowledge of tigers in India. But James was critical of scholastic interpretation of the mental inexistence of the object of consciousness. This is linked to the reserve with which James treated any self-sufficient Idealism, as will be emphasized below.

James did not elaborate a concept of intentionality which was precise in a phenomenological sense. All the same, the intellectual foundation of James's psychology is a critical adoption of the concept of intentionality. The use of 'intending' in the sense of 'pointing at' appears first in James's lecture 'The Function of Cognition', delivered in 1884 (1948:319ff.). In Principles of Psychology this idea is implicitly developed in the chapter on conception - for example, when James states that 'the mind can always intend, and know when it intends, to think of the Same'; or in a more substantiated form when he talks of 'our intention to think of the same outer things' (James, 1902, I: 459). In effect, for James 'concept' is equivalent in meaning to 'intentionality'.

James uses the concept of intentionality in the same dual sense that Brentano 
had emphasized: each object is given in consciousness, 'as simply thought of, and as admitted or denied' (Brentano, cited in James, 1902, II: 286). But James lends the idea of intentionality a more dynamic form than Brentano had:

1 intentional objects relating to diverse intentional actions can be identical; and 2 intentionality implies selective activity on the part of consciousness.

The concept of intentionality was adopted by Husserl in this modified, dual form. It was integrated into Husserl's descriptive psychology as mediated and modified by James; the transcendental modification came later. The phenomenological concept of intentionality leads us to review some additional constitutive elements of James's psychology.

\section{THE 'SENSE OF SAMENESS'}

James does not treat the experience of reality as isomorphic in relation to an unchanging object, like an empiricist with a representational realism; he instead pursues an 'acquaintance with things' derived from experience. The genetically oldest form of experience is the 'pure experience' of sensibility. The most elementary form of the structuration of such experience is effected not by reflective thought, but through the feeling of identity, the 'sense of sameness'.

Prior to every judgement on the external world, or prior to reflection upon 'introspection', 'reality' is the ontogenetic product of the felt sameness of entities:

The first spaces, times, things, qualities, experienced by the child probably appear... as simple beings, neither in nor out of thought. But later, by having other thoughts than this present one, and making repeated judgements of sameness among their objects, he corroborates in himself the notion of realities, past and distant as well as present. (James, 1902, I: 272)

Thus James explicitly leaves open the question, with which Husserl later dealt with such penetration in his Logical Investigations, of whether there is such a thing as an equality between things and events in the world. ${ }^{5}$ Psychologically it is sufficient for the feeling of identity to be elevated into the essential principle of a structured experience of reality. Otherwise, consciousness would simply be a stream in which nothing happened twice, or nothing comparable. Ultimately there would be no experience even where the identity of things outside us were assumed:

Without the psychological sense of identity, sameness might rain down upon us from the outer world for ever and we be none the wiser. With the psychological sense, on the other hand, the outer world might be an 
unbroken flux, and yet we should perceive a repeated experience. (James, 1902, I: 460)

The decisive consequence for phenomenology of James's extensive analyses is that in experience there are 'cores of constancy' that provide it with structure. 'This sense of sameness is the very keel and backbone of our thinking' (James, 1902, I: 458).

This possibility of being intentionally oriented towards the same $e^{6}$ is, for James, 'the law of constancy in our meanings', where the constitutive nature of psychical activity in constructed lived reality first fully reveals itself. This law is 'the most important of all the features of our mental structure' (1902, I: 460).

James's doctrine of conceptions is inseparably linked to the feeling for sameness. Together, both moments provide the basis for the 'descriptive psychology', which Husserl developed in his Logical Investigations.

\section{'CONCEPT AND CONCEPTION'}

The sense of identity has the cognitive function of temporally isolating concepts as the constancies of lived experience through the conception of experience.

The function by which we thus identify a numerically distinct and permanent subject of discourse is called CONCEPTION; and the thoughts which are its vehicles are called concepts. (James, 1902, I: 461)

James's 'concept' is, like Husserl's notion of intentionality, neutral with respect to the ontological question of the reality of things. Conception in James, and intentionality in Husserl, are both determined by the function of a state of consciousness in which a something is always something specific, the connection of conscious lived experience to something.

A given object, a thing, an occurrence, a material relation, an ideal law and so on is conceived when it can be identified as this opposed to the other and differentiated from the other to which it is opposed. So, for example, even a polyp would have conceptions if the feeling of identity ever occurred to it: 'A polyp would be a conceptual thinker if a feeling of "Hollo! thingumbob again" ever flitted through its mind' (James, 1902, I: 463).

A 'round square' or a 'black-white-thing' are also absolutely defined concepts: 'it is a mere accident, as far as conception goes, that they happen to stand for things which nature never lets us sensibly perceive' (James, 1902, I: 463). If a piece of white paper becomes scorched black this transformation of the object 'paper' does not alter the concepts 'white' and 'black'. On the contrary: the two immutable concepts enable us first to define the change in the paper and thence to arrive at the concept of difference. 
Thus, amid the flux of opinions and of physical things, the world of conceptions, or things intended to be thought about, stands stiff and immutable, like Plato's Realm of Ideas. (James, 1902, I: 462)

James undermines the antagonism of empiricism and apriorism with his doctrine of conceptions, and in this shows himself to be the epistemological precursor of phenomenology. The anonymity of consciousness gains its personal, qualitative diversity of experience from the conceptions of perceptible objects in the world. This is simply another expression for the 'eidetic intuition' which Husserl categorically extended. Edmund Husserl integrated into his doctrine of intentional being James's psychological finding with respect to the prereflexive genesis of sameness in experience: intended identities are at the heart of the phenomenology of experience (Husserl, 1976: $73 \mathrm{f}$., 180 f.).

If James characterizes conceptions as autonomous with respect to external reality - it makes no difference here whether we are talking of a steam engine in external reality, an inner fiction like a mermaid, or a pure rational entity such as difference or nonentity (James, 1902, I: 461) - this conceptual ordering of reality, extended in his later radical empiricism, anticipates Husserl's doxological modalities (Edie, 1970:506) as well as his 'concept of the lived world' (Wilshire, 1968: 171).

Concepts are not the building-blocks of reality, as bricks are of a house. ${ }^{8}$ Conceptions are rather the manner in which that which is lived gains its consistent form as experience. Thus James's substantive usage of 'conception' anticipates intentionality; and 'concept' is the intentionally constituted meaning. Within the stream of perceptions things have to be conceptualized as such, so that they may be recognized as identical. That is the function of the 'sense of sameness'. Lived experiences are intentionally structured by concepts. Pure perceptions, without concepts, are meaningless; just as, on the contrary, conceptions without perceptions represent constructed thought-objects.

Let us follow the manner in which the descriptive psychology of Husserl's Logical Investigations picks up this point and takes it further. Husserl distinguishes the 'object as it is intended' from the 'object which is intended' $(1980, \mathrm{II} / 1: 400)$. If the object were identical with the act of consciousness intending the object, the idea of sameness in experience that James had arrived at would not be possible. Husserl had a background in mathematics and he liked clarifying such issues with arithmetical problems. Objects like numbers are neither external things, nor are they tied to internal numbers. 'Ideal objects' of this kind, as Husserl called them, are not in any way limited to sciences such as mathematics and logic. They are to be found as 'meanings' in every sensible experience of singular objects. The concretely perceived lion might appear only for a short moment before one's eyes, then as an individual go the way of every terrestrial thing. But its meaning was perceived at the same time; the lion is a concrete example of the 'ideal unity' of its species. The general meaning of a lion 
is just as timeless and ideal as that of number. It is meaningless to endow the 'general object, lion' with a definite location in the world of matter or of the intellect.

More precisely: the meaning of the concretely perceived lion is indifferent with respect to the distinction of individual concrete thing from general abstract concept. It is not that an individual animal first appears and then becomes through a process of abstraction part of a general species; instead, the individual (concrete) and the general (abstract) are perceived simultaneously. The perception of the species is realized in the perception of the individual. Meaning, it could be said, mediates between the general and the specific, the meaning of the latter being grasped on the basis of the former, or rather as an exemplar of the former.

In Husserl's descriptive psychology the general, the same, has to be equated with the 'meaning' of the object:

The nature of 'meaning' is as directly accessible to us as are colour and tone.

It can be defined in any more general manner, it is a descriptive ultimate.

(Husserl, $1980 \mathrm{II} / 1$ : 183; emphasis added)

In the Logical Investigations Husserl uses the term 'meaning' (Bedeutung) as a synonym for 'sense' (Sinn), as he later defined it in Ideen I: sense in the Logical Investigations is the concept of a 'meaningful being'. Thus Husserl can also write that similarity presupposes 'essential unity'. 'Essence' or Eidos constitutes the inner structure of lived experience's immanent order.

The manner in which Husserl introduces the concept of meaning in his Logical Investigations is not surprising if one is familiar with James's psychology. The supersession of the metaphysical distinction between subject and object that we find in Husserl's descriptive psychology comes from James. Meaning is that which is lived through in consciousness. It is the intentional tissue in which consciousness and conscious content are united. Thus Husserl dubs the experiencing of meanings as 'intentional experience' and in this way defines the expression 'act' (Husserl, 1980 II/1:379).

Acts are interpretative. 'Lived experience is the interpretation of the world, the world is itself a signifying object' (Husserl, $1980 \mathrm{II} / 1$ :386f). For this reason he emphasizes that the possible existence of 'objective' being is of no consequence. What is meant cannot be grasped through such categories, for it is neither subjective, empty sense, nor objectified non-sense.

In the Ideen the intended, meant object is thus called noëma and the intended, meaningful act noêsis (Husserl, 1976: $\$ 87 \mathrm{f}$.). Husserl's concept of noëma is as neutral with respect to the question of the reality of the intended as is James's definition of the concept.

We have at this point to introduce a further direct borrowing by Husserl from James: from the latter's definition of the concept there follows the way in which all lived experience is structured within a distinct horizon. 


\section{HORIZONAL INTENTIONALITY}

The intended object is apprehended only in its parts; so, for example, the idea 'house' can refer to the doors, to the roof, to the windows and so on. James called these segments of the complete object 'topics'.

It is at most your 'fractional object'; or you may call it the 'topic' of your thought, or the 'subject of your discourse'. But the Object of your thought is really its entire content or deliverance, neither more nor less. (James, 1902, I:275)

James's concept of object comprehends the entirety of its conscious content, however complex this might be (James, 1902, I: 276).

To every experience of something there therefore belongs a topic, surrounded by a fringe of material that is not part of that topic. ${ }^{9}$ Together, they constitute the integrity of conscious lived experience. This is James's anticipation of what Husserl, drawing directly on James, later called the horizonal nature of lived experience. The structuration of lived experience by time and by topic is the condition for something being experienced as something.

In Die Krisis der europäischen Wissenschaften und die transzendentale Phänomenologie (The Crisis of European Sciences) Husserl wrote that, so far as he was aware, James was the first to draw attention to the horizonal nature of lived experience (1954:269). In his Ideen this concept - he refers in the same sense to 'halo' and 'background' (Husserl, 1976, III/1:186, n. 1) - is given the function of unifying the variety of intentional objects and thus creating a continuity of lived objectified experience. The consciousness of horizonality belongs to the stream of experience. Within the stream of intentional (noëtic) suppositions the noëmatic correlate is always constituted within a particular horizon. Husserl's retractions dating from the years 1912-39 that supplement Ideen I provide evidence for the central methodological significance of this concept of horizon for the further development of phenomenology, up to the explicit treatment of the problematic of the lived world (1976, III/2:583f.). Within this perspective it becomes necessary to consider the nature of the world', for the horizon does not limit experience in a rigid fashion, but rather varies with it: one horizon is constituted within another wider, more comprehensive horizon, until the horizon of all horizons becomes the 'world horizon'.

In sum, it is evident that commentators have identified Husserl's conception of the lived world far too closely with Heidegger's Being and Time. More careful consideration shows that Husserl's treatment of the world and its structuration can be traced back to his reception of James's psychology. 


\section{WILLIAM JAMES AND HUSSERLIAN PHENOMENOLOGICAL PSYCHOLOGY}

There is always a danger in retrospectively treating a thinker as a 'precursor' to path-breaking insights. In the case of James, Schwehn has also drawn our attention to the 'presentist fallacy', and suggested that the Principles of Psychology is not an anticipation of phenomenology, but rather an expression of James's experience of his sociocultural milieu (1982:454). This cannot be disputed; but more can be said. Today we know that Husserl, in the mid-1890s, gave up his own plan of writing a general psychology after becoming acquainted with James's work. As he himself testified, he felt that 'James had already said what he had wanted to say' (Spiegelberg, 1984: 102). Thus we have Husserl's own testimony as a warrant for treating James as a pioneer of phenomenological psychology.

However, after his 'transcendental turn' Husserl distanced himself increasingly from the descriptive psychology of Logical Investigations. His phenomenology became increasingly a general system of all possible sciences - an intellectual claim which many of his students viewed with scepticism, or even rejected. This was especially true of those among them who had received a scientific training, as in the case of Moritz Geiger, who had a background in the experimental psychology of Wilhelm Wundt. ${ }^{10}$ James remained in advance of Husserl for these members of the phenomenological movement. His Principles of Psychology outlined the manner in which a phenomenologically oriented psychology could be conceived in such a way as to integrate subjectivizing and objectivizing methodology. Husserl never achieved this. It was because of this that Wundt came to dominate continental European psychology, while in the United States James became famous only as one of the founders of pragmatism.

My argument runs as follows: James's concept of experience elevated psychology into an empirical, phenomenological discipline by translating into American the preliminary work done in Europe. This process of basic conceptual translation can be shown at work if we consider those thinkers in the European tradition who are generally identified as the precursors of Husserlian phenomenology. So that we can see how James took up phenomenological approaches in pre-Husserlian psychology, approaches which were then rediscovered in Europe after Husserl, some brief comments on the relation of James to Carl Stumpf and Ernst Mach are needed.

Spiegelberg has established beyond doubt that James's great interest in Brentano's psychology, an interest matching that of Husserl, derives from his acquaintance with Carl Stumpf (1848-1936) (Spiegelberg, 1984:63). Stumpf had met James during 1882 in Prague (Stumpf, 1924: 12) and became his closest friend in German academia; their friendship is expressed in a correspondence that continued unbroken until James's death, and in Stumpf's sensitive account of James's life, character and work. "' Stumpf declared James's psychology 'the best 
of all psychologies' (Spiegelberg, 1984:62). In return, Stumpf was James's favourite experimental psychologist and for a time James toyed with the idea of integrating an entire section of Stumpf's 'psychology of tones and sounds' into his Principles (Köhler, 1928: 1).

James took over the Stumpfian distinction between phenomenon and function, as well as the nativistic treatment of the perception of space. He writes in connection with his discussion of theorists dealing with spatial perception: 'Stumpf seems to me the most philosophical and profound of all these writers; and I owe him much' (James, 1902, II: 282).

Stumpf's concept of phenomenon or of appearance is basically determined by its self-sufficiency, or by its capacity to be directly experienced. Everything which cannot be directly experienced is ordered by Stumpf's approach to 'entities'; to this category belong entities created by the intellect such as concepts, values, judgements and so forth. Functions are by contrast psychical acts. They form the law-governed coherence of the spirit, or 'the manner in which the spiritual organism works' (Stumpf, 1907:7). We might find a similar formulation in James, but not in Husserl. For behind this statement there lies the conviction that the psychology of spiritual acts cannot be reduced down to a psychology of the ego (Stumpf, 1907: 9, n. 2). This places the break with Husserl's phenomenology right before our eyes. At the very moment when, in 1906, Stumpf explicitly adopted the term 'phenomenology', Husserl definitively moved away from Stumpf. ${ }^{12}$

A parallel can be traced here with the manner in which James and Husserl diverged in their judgement of Ernst Mach's doctrine of sensations. Husserl saw in Mach only a consistent proponent of a Humean positivism, in which 'the physical world was dissolved into complex sensations, into colours, sounds, impressions, etc., where even the psychic domain became supplementary complexes of the same elements or of other "sensations"' (Husserl, 1971b: 14).

It was otherwise with James. In Mach he found key arguments for the revision of the concept of experience; for example, the supersession of the psychic dualism which at that time appeared to represent the sole alternative to materialism. The concept of 'pure experience' that can be found in James's later work bears clear traces of Mach's 'neutral monism', as James called it. James met Mach during the same year that he had first met Stumpf, and this likewise led to a lasting friendship.

There is a dialectical relationship between James, Husserl and phenomenological psychology: the more that Husserl turned away from descriptive psychology and dedicated his efforts to transcendental phenomenology, the more did James shift from being a partisan of phenomenology to being its critic. This at any rate was the effect which his work had on Husserl's alienated students. At the first glimmerings of Husserl's transcendental turn criticism was voiced among his students; a secession from Husserl began.

The divergence began with the emergence of a distinction between a 
phenomenological psychology that, in James's sense, retained the prospect of an integration of objectivating methods into psychology; and that of a 'pure' psychology whose object was solely the transcendental structures of consciousness. Husserl's transcendental phenomenology concerned itself exclusively with the performative realizations of consciousness, and is therefore able to disregard, or bracket off, its objects and substantive contents. For James and the psychological critics of Husserl on the other hand, their attention remained fixed upon the object given in consciousness and the form of its genesis out of the pre-reflective stream of consciousness. In conclusion we will examine this problem of bracketing-off.

The introduction of this bracketing procedure into Husserl's phenomenology made the problem of 'phenomenological idealism' increasingly urgent. The core of this problem lies in the neglect of the inherent nature of the intended object. Husserl is thus able to demonstrate almost all of his analyses with examples from arithmetic (ideal objects!). He is concerned only to illuminate thought experiences. Stumpf, for example, raised criticisms in terms that could equally well have come from James: Husserl had not shown that there was no, nor that could there be, species of liverwort or of eye infections (Stumpf, 1939:190). Husserl's phenomenological idealism went too far with its strict methodological separation of act and object. As James in his later works moved increasingly towards a pluralistic universe, so did Husserl move more and more towards a universal idealism.

The expression 'pure experience' means in James's later writings the totality of all possible things and events, manifest in all their infinite variety, in different 'worlds' and functions, without, however, ceasing to be 'themselves'. The distinction between a 'content' and a consciousness without qualities is, in pure experience, without meaning. Pure experience is rather the expression of the qualitative variety of 'stuff', from which experience arises: 'there is no general stuff of which experience at large is made. There are as many stuffs as there are "natures" in the thing experienced.' Pure experience, he goes on, 'is made of that, of just what appears, of space, of intensity, of flatness, brownness, heaviness, or what not' (James, 1912:26-7).

Universal idealism is the direct consequence of Husserl's conception of science, and not an unintended outcome. Husserl clearly stated his position on this in the afterword to Ideen I, published in 1930, talking of transcendental-phenomenological idealism as a 'fearless consequence (that is not to everyone's taste)' (Husserl, 1971a: 149). This kind of idealism embraced the 'essential relativity' of the real world in a transcendental subjectivity (Husserl, 1971a: 153). It was this form of idealism which Husserl declared to be the sole possible mode of approach to an understanding of that which made 'sense' for us in the world. With regard to the illumination of possible regions of constitutive being, transcendental-phenomenological idealism was a 'universal idealism' (Husserl, 1971a: 152). Husserl's idealism was based upon 
the priority of the ego qua cogito, of the sense-forming subjectivity (= Egologie).

Stumpf, together with the writings of James, represented a counterweight to the growing virulence of idealism in European psychology; they became objectivist critics of the increasing idealism of phenomenology as practised by Husserl. The factor uniting all proponents of objectivizing phenomenology was a conviction that phenomenology should not direct itself just to the act, but had to be inferred from the object. Husserl delivered a blanket dismissal of his psychological critics, calling them 'realists' and 'ontologists' (Herzog, 1992: $246 \mathrm{ff}$.); but in adopting such an emotionally coloured position he failed to consider what New Realism might be - it was in any event not based upon the old equation of knowledge and the known.

From our present-day perspective, the use of James to criticize Husserl's one-sided phenomenology of the act is historically justified. Following his Habilitation in 1907, the originator of objective phenomenology, Moritz Geiger, studied for a year, chiefly in Harvard, where he got to know Josiah Royce and James personally. Geiger kept up his contacts in America. In 1925, and then again in 1935, he was a visiting professor at Stamford. After 1933, when the Nazis removed him from his chair in Göttingen, he was appointed to a permanent position at Vassar College. The oration at his funeral in 1937 was given by Ralph Barton Perry, the friend and biographer of William James (Spiegelberg, 1984:202).

Geiger's connections with America are noteworthy, since the influence of James in Europe as the pioneer of an empirical phenomenological psychology has to be seen in contrast to Royce's idealist absolutism. Today we know that Husserl was reading Royce intensively at precisely the time that his transcendental idealism was first taking shape. The American Winthrop Bell, who studied with Husserl in Göttingen between 1911 and 1914, reports that Husserl saw James's work as a critical reaction to Royce's idealism - and in Husserl's eyes it was of course James, and not Royce, whose position was suspect. By contrast, Husserl converged with Royce's position to such an extent that extensive parallelisms are evident in their writings. Husserl defended Royce from the criticisms raised in Bell's dissertation, accusing Bell of insufficient respect for this 'important thinker'. ${ }^{13}$

It is important to note that Royce developed a pre-explicit form of three reductions that lead to absolute and indubitable truth (Goicoechea, 1975). The details of Royce's system are of no great interest here. Nonetheless, the objective of this reduction is in Royce and Husserl the same, as far as its idealistic implications are concerned. There is a bifurcation in the line of development of phenomenology, and we can trace this back to the direct influence of Royce and Husserl on the one side, and James on the other. The first branch is transcendental, where Husserl built upon Royce after the Logical Investigations; the second is the pluralistic New Realism, the objectivist phenomenology, or the mundane (empirical) phenomenological psychology of James. 
If we look back once more, then we see that James was not only the precursor of Husserl, but was in some respects far in advance of him. Today, the psychologist studies James, and not Husserl, to discover how an objective psychology of objects can be integrated with a subjective psychology of lived experience. James demonstrated quite clearly, as a phenomenologist, the boundaries of the most minute methodological analytical entities. If these are undermined we end up with methodological artefacts which no longer have anything in common with phenomenology. After the work of James, that holds for everything in the psychic domain, as well as for both sides of the two opposing camps in psychology, that of the human sciences and that of the natural sciences:

It is not that we are all nature but some point which is reason, but that all is nature and all is reason too. We shall see, damn it, we shall see! (H. James, 1920: 153)

\section{Technische Universität Berlin}

\section{NOTES}

1 The uncut version of Principles has not to this day been published in German. This work nevertheless represents the decisive breakthrough in the development of phenomenological psychology, possibly for phenomenology itself. The role played by William James in the genesis of phenomenological psychology was for many years simply disregarded by German writers. Not until 1961 did Linschoten undertake the first systematic interpretation of James's work with respect to this issue. See for the reception of James's work Schwehn (1982: 453); Bruder (1982); Bernstein (1977: 103); Edie (1970; 1987); Wild (1980); Wilshire (1968); Schütz (1966: 1-15; 1962: Pt III); Gurwitsch (1975); Spiegelberg (1984).

$2 \mathrm{He}$ is referring here to 'Psychologische Studien zur elementaren Logik', Philosophische Monatshefte 30 (1894): 150-91.

3 This is discussed further below.

4 This principle was later articulated by Husserl in the following terms: 'that every original intuition is a just source of knowledge, that everything that appears to us intuitively original must simply be accepted for what it is, but only within the limits within which it appears' (Husserl, 1976:51).

5 'We are psychologizing, not philosophizing. That is, we do not care whether there be any real sameness in things or not, or whether the mind be true or false in its assumptions of it' (James, 1902, I: 459-60).

6 'The thing we mean to point at may change from top to bottom and we be ignorant of the fact. But in our meaning itself we are not deceived; our intention is to think of the same' (James, 1902, I: 460).

7 This does not mean that concepts are necessarily universal in character. The concept 'white' can mean the particular white of this snow in this bit of countryside, but can also be related to all possible things to which this sort of 'whiteness' applies. The 
concept becomes, ultimately, a 'floating adjective' (Bradley). We can either individualize or universalize the concept 'white', but in so doing derive two distinct concepts: 'whiteness is one thing, the whiteness of this sheet of paper another thing'; here James refers to Reid's Intellectual Powers, Essay V, Ch. 3 (James, 1902, I: 473).

8 With Bergson in mind James wrote that 'Concepts are notes, views taken on reality, not pieces of it, as bricks are of a house' (James, 1919:200).

9 James uses the expressions 'horizon', 'halo' and 'fringe' synonymously (Wilshire, 1968: 87).

10 The sole meeting of working experimental psychologists that Husserl attended was the VIth Congress for Experimental Psychology in Göttingen during April 1914 - after, therefore, the publication of the Ideen. It was here that Husserl delivered his famous statement that phenomenology neither was descriptive psychology nor contained any part of other psychological discourses (Spiegelberg, 1972:33). This amounted to a break with Husserl's own psychological students.

11 Out of friendship Stumpf dedicated this essay to the brother of William James, the writer Henry James (Stumpf, 1928).

12 In his note to $\$ 86$ of Ideen I Husserl referred to Stumpf's phenomenology as mere 'Hyletik', a doctrine of sensations.

13 According to a letter from Bell to Spiegelberg, in Spiegelberg, 1984: $128 \mathrm{f}$.

\section{BIBLIOGRAPHY}

Bernstein, R. J., ed. (1977) William James. A Pluralistic Universe. Cambridge, MA: Harvard University Press.

Biemel, W. (1956) 'Edmund Husserl. Persönliche Aufzeichnungen', Philosophy and Phenomenological Research 16:293-302.

Bruder, K.-J. (1982) Psychologie obne Bezeusstsein. Frankfurt am Main: Suhrkamp.

Chisholm, R. (1960) Realism and the Background of Phenomenology. New York: Free Press.

Edie, J. M. (1970) 'William James and Phenomenology', Review of Metaphysics 23:481-526.

Edie, J. M. (1987) William James and Phenomenology. Bloomington: Indiana University Press.

Fullerton, G. S. (1908) 'The New Realism', in Essays Philosophical and Psychological in Honor of William James. London: Longman Green, 1-49.

Goicoechea, D. (1975) 'Royce and the Reductions', in P. J. Bossert (ed.) Phenomenological Perspectives. The Hague: Nijhoff, 31-46.

Graumann, C. F. (1991) 'Phänomenologie und Psychologie - ein problematisches Verhältnis', in M. Herzog and C. F. Graumann (eds) Sinn und Erfabrung. Heidelberg: Asanger, 22-42.

Gurwitsch, A. (1975)

Herzog, M. (1992) Phänomenologische Psychologie. Heidelberg: Asanger.

Husserl, E. (1952) Ideen zu einer reinen Pbänomenologie und phänomenologischen Philosophie, Vol. II. The Hague: Nijhoff.

Husserl, E. (1954) Die Krisis der europäischen Wissenschaften und die transzendentale Phänomenologie. The Hague: Nijhoff. 
Husserl, E. (1969) Zur Phänomenologie des inneren Zeitbewusstseins. The Hague: Nijhoff.

Husserl, E. (1971a) Ideen zu einer reinen Phänomenologie und phänomenologischen Philosophie, Vol. III. The Hague: Nijhoff.

Husserl, E. (1971b) Philosophie als strenge Wissenschaft. Frankfurt am Main: Klostermann.

Husserl, E. (1973) Die Idee der Phänomenologie. The Hague: Nijhoff.

Husserl, E. (1976) Ideen zu einer reinen Phänomenologie und phänomenologischen Philosopbie, Vol. I/1. The Hague: Nijhoff.

Husserl, E. (1980) Logische Untersuchungen I, II/1, II/2. Tübingen: Niemeyer.

James, H. (ed.) (1920) The Letters of William James, Vol. I. New York: Longman, Green. James, W. (1902) The Principles of Psychology, 2 vols. London: Macmillan.

James, W. (1909) A Pluralistic Universe. New York: Longman, Green.

James, W. (1912) Essays in Radical Empiricism. New York: Longman, Green.

James, W. (1919) Some Problems of Philosophy. New York: Longman, Green.

James, W. (1948) Pragmatism. A New Name for Some Old Ways of Thinking. Together with Four Related Essays Selected from the Meaning of Truth. New York: Longman, Green.

James, W. (1983) Essays in Psychology. Cambridge, MA: Harvard University Press.

Kallen, H. M. (1914) William James and Henri Bergson. Chicago, IL: University of Chicago Press.

Köhler, W. (1928) 'Carl Stumpf zum 21.April 1928', Kant-Studien 33: 1-3.

Linschoten, J. (1961) Auf dem Weg zu einer phänomenologischen Psychologie. Berlin: de Gruyter.

Miller, D. L. (1976) 'William James and the Specious Present', in W. R. Corty (ed.) The Philosopby of William James. Hamburg: Meiner, 51-79.

Schütz, A. (1962) Collected Papers, Vol. I. The Hague: Nijhoff.

Schütz, A. (1966) Collected Papers, Vol. II. The Hague: Nijhoff.

Schwehn, M. R. (1982) 'Making the World: William James and the Life of the Mind', Harvard Library Bulletin 30: 426-54.

Spiegelberg, H. (1972) Phenomenology in Psychology and Psychiatry. Evanston, IL: Northwestern University Press.

Spiegelberg, H. (1984) The Phenomenological Movement. The Hague: Nijhoff.

Stumpf, C. (1907) 'Erscheinungen und psychische Funktionen', Abhandlungen der preussischen Akademie der Wissenschaften.

Stumpf, C. (1924) 'Carl Stumpf', in R. Schmidt (ed.) Die Pbilosophie der Gegenwart in Selbstdarstellung, Vol. 5, 205-65.

Stumpf, C. (1928) William James nach seinen Briefen. Berlin: Heise.

Stumpf, C. (1939) Erkenntnislebre, Vol. I. Leipzig: Barth.

Wild, J. (1980) The Radical Empiricism of William James. Westport, CT: Greenwood.

Wilshire, B. (1968) William James and Phenomenology. Bloomington: Indiana University Press. 